DEPARTMENT OF THE INTERIOR

UNITED STATES GEOLOGICAL SURVEY

\title{
SURFICIAL GEOLOGIC MAP OF THE MOODUS QUADRANGLE, CONNECTICUT
}

By Dennis W. O’Leary

Prepared in cooperation with the

STATE OF CONNECTICUT

Geological and Natural History Survey 